\title{
Airway management in the patient with potential cervical spine instability: Continuing Professional Development
}

\author{
Arnaud Robitaille, MD
}

Received: 26 May 2011/Accepted: 14 September 2011/Published online: 27 October 2011

(C) Canadian Anesthesiologists' Society 2011

\begin{abstract}
Purpose Securing the airway of a patient with a potentially unstable cervical spine (C-spine) is a complex and challenging task. The objective of this continuing professional development module is to review the current knowledge essential for airway management in the face of potential C-spine instability and, at the same time, to underline areas of uncertainty and limitations in the literature.

Principal findings In low-risk patients-defined by strict criteria derived from large multicentre studies-the $C$-spine can be considered stable or "cleared" without imaging. In all other patients, at least a thin-section computed tomographic examination of the spine from the occiput to $T 1$ should be obtained, including sagittal and coronal multiplanar reconstructed images. Until the C-spine is cleared, it should be immobilized in the neutral position using a rigid cervical collar, sandbags, tape, and a backboard. During airway management, the anterior part of the cervical collar should be removed, and manual in-line stabilization should be applied. Some airway techniques, such as fibreoptic bronchoscopy and the Trachlight ${ }^{\circledR}$, have been shown to induce less C-spine movement than direct laryngoscopy; however, the impact of such airway management on outcome is uncertain.

Conclusion Adequate airway management in the patient with potential $C$-spine injury demands an understanding of $C$-spine anatomy, the criteria required to clear the C-spine, and the indications, techniques, and pitfalls of $C$-spine
\end{abstract}

A. Robitaille, MD ( $\square)$

Département d'Anesthésiologie, Centre Hospitalier de

l'Université de Montréal, Pavillon Notre-Dame,

1560 Sherbrooke Est, Montreal, QC H2L 4M1, Canada

e-mail: arnaud.robitaille@umontreal.ca immobilization. When choosing an airway technique, minimization of $C$-spine motion should be considered, but the method of choice should also incorporate the broader clinical context.

\section{Objectives of this Continuing Professional Development (CPD) module}

After reading this module, the reader should be able to:

1) Achieve a basic knowledge of cervical spine (C-spine) anatomy and biomechanics;

2) Understand how C-spine stability is assessed both clinically and radiologically;

3) Appreciate the efficacy, benefits, and risks of stabilization maneuvres; and

4) Evaluate the impact of different airway techniques in terms of both C-spine movement and clinical outcome.

\section{Summary review}

Securing the airway of a patient with a potentially unstable cervical spine (C-spine) is a complex and challenging task. The anesthesiologist must deal simultaneously with two important and potentially competing objectives, namely, minimizing $\mathrm{C}$-spine movement to prevent neurological deterioration and securing the patient's airway both safely and efficiently. Deciding on the optimal course of action is complicated further by our incomplete knowledge about the relationship between various airway techniques, the $\mathrm{C}$-spine movement these techniques produce, spinal cord injury, and patient outcome.

Instability of the C-spine is considered to occur when physiological loading of the injured spine causes patterns 
of vertebral displacement that jeopardize the spinal cord or nerve roots. ${ }^{1}$ Instability of the $\mathrm{C}$-spine is most frequently associated with trauma, but it can also involve other mechanisms, such as a congenital anomaly, systemic inflammation, malignancy, or infection. Airway management in patients with potential C-spine instability may be required because of respiratory or hemodynamic instability or because of an elective or emergency procedure requiring general anesthesia.

In this article, we briefly review the current knowledge essential for airway management in the face of potential C-spine instability and, at the same time, we underline areas of uncertainty and limitations in the literature.

\section{C-spine anatomy and biomechanics}

The C-spine is composed of the skull base and seven cervical vertebrae (Figs. 1 and 2). Its lower portion (C3-C7) is made up of five vertebrae that are anatomically similar to their thoracic and lumbar counterparts, except for the presence of bilateral transverse foramina through which the vertebral arteries ascend. Its upper portion, the occipitoatlantoaxial complex, comprises three bony elements with distinct anatomical characteristics, i.e., the base of the skull (occiput); the atlas (C1), a ring-like vertebra with no vertebral body and no spinous process; and the axis (C2), characterized by its odontoid process (or dens) protruding upwards from its vertebral body into the ring of $\mathrm{C} 1$.

The bony structure of the $\mathrm{C}$-spine is stabilized by vertebral discs, facet joints, the paravertebral muscles, and numerous ligaments. The transverse ligament tethers the odontoid process to the posterior surface of the anterior arch of $\mathrm{C} 1$. The apical and alar ligaments extend from the odontoid process to the anterior margins of the foramen magnum on the skull base. The anterior and posterior spinal ligaments ascend, respectively, on the anterior and posterior surfaces of the vertebral bodies, and the ligamentum flavum connects adjacent lamina. Finally, the interspinal and supraspinal ligaments join the spinous processes together. In the spinal canal, the spinal cord is separated from the bony and ligamentous elements by the subarachnoid space which is filled with cerebrospinal fluid.

The C-spine supports movement in three axes (flexion/ extension, rotation, and lateral bending), but airway manipulations involve flexion and extension almost exclusively. Motion is not distributed uniformly throughout the C-spine. ${ }^{2}$ Occiput-C1 allows $15-20^{\circ}$ of extension but only about $5^{\circ}$ of flexion, while $\mathrm{C} 1-\mathrm{C} 2$, most important in axial rotation, allows about $10^{\circ}$ of both flexion and extension. Approximately $65^{\circ}$ of further flexion/extension is gained from the lower $\mathrm{C}$-spine, with most of it being attributable to the caudal segments.

\section{Assessing C-spine stability}

Establishing whether a patient's C-spine is stable, often referred to as "clearing the C-spine", is a complicated task with important consequences both for the patient and from a medico-legal point of view. Generally, anesthesiologists should not be the decision-makers regarding the stability of

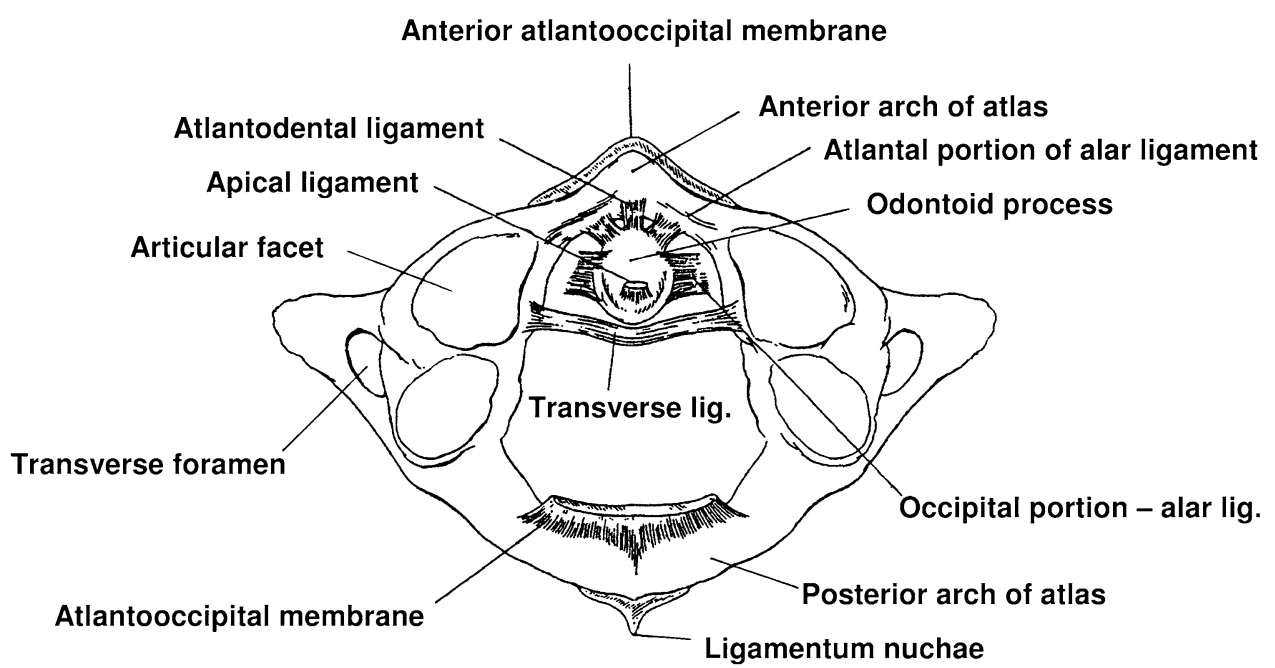

Fig. 1 Axial view of the atlantoaxial joint at the level of $\mathrm{C} 1$ showing the ligaments. Anterior is up, posterior is down. With permission from reference ${ }^{21}$ : Crosby ET. Airway management in adults after cervical spine trauma. Anesthesiology 2006; 104: 1293318
Fig. 1 Vue axiale de l'articulation atlanto-axiale au niveau de $\mathrm{C} 1$, montrant les ligaments. Le côté antérieur est en haut, le côté postérieur en bas. Avec la permission de notre référence ${ }^{21}$ : Crosby ET. Airway management in adults after cervical spine trauma. Anesthesiology 2006; 104: 1293-318 
Fig. 2 Sagittal section of the cervical spine with the ligaments outlined. With permission from reference ${ }^{21}$ : Crosby ET. Airway management in adults after cervical spine trauma. Anesthesiology 2006; 104: 1293-318

Fig. 2 Section sagittale de la colonne cervicale, montrant les ligaments. Avec la permission de notre référence ${ }^{21}:$ Crosby $E T$. Airway management in adults after cervical spine trauma. Anesthesiology 2006; 104: 1293-318

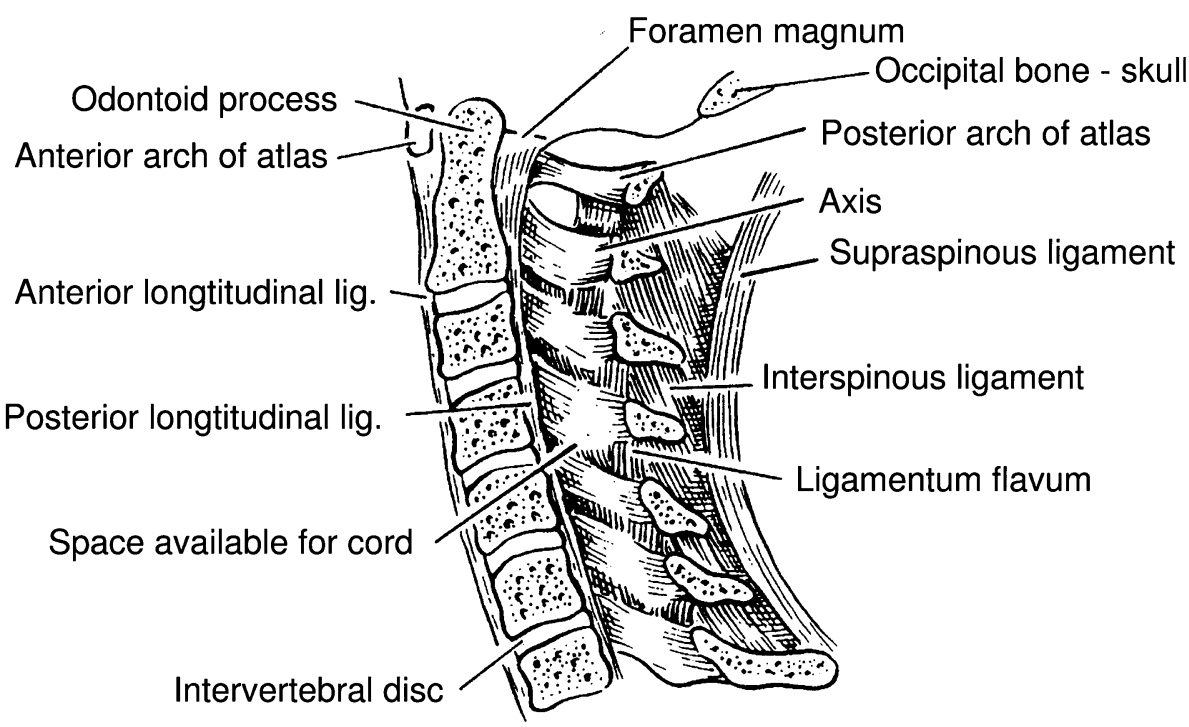

the C-spine; however, they must understand how $\mathrm{C}$-spine stability is assessed, and they should maintain a high index of suspicion for C-spine instability considering the consequences of missed injuries. ${ }^{3}$ Since most of the literature concerning $\mathrm{C}$-spine assessment comes from the trauma setting, we restrict our discussion to trauma patients. Nevertheless, many of the same principles can apply to patients presenting with other anomalies that may be congenital, malignant, inflammatory, infectious, or degenerative in nature.

Assessing C-spine stability in a patient usually involves relying on a combination of medical history, physical examination, and imaging studies. The latest guidelines on this topic have recently been updated by the Eastern Association for the Surgery of Trauma (EAST). ${ }^{4}$

\section{Low-risk patients}

History and physical examination form the basis of the initial stratification of patients presenting with potential $\mathrm{C}$-spine instability, and they determine whether radiological studies are indicated. In a minority of patients, i.e., those with a very low probability of having significant injury, it is possible to clear the $\mathrm{C}$-spine without imaging. Two strategies to identify these low-risk patients have been tested in large multicentre studies involving thousands of trauma patients (Table 1). According to the simple approach of the National Emergency X-Radiography Study Group (NEXUS), ${ }^{5}$ a strategy endorsed by the EAST guidelines, ${ }^{4}$ it is reasonable to clear the $\mathrm{C}$-spine without imaging in an adult blunt trauma patient presenting no midline cervical tenderness, no focal neurological deficit, normal alertness, no intoxication, and no painful distracting injury. Another strategy, the Canadian C-spine Rule (CCR), ${ }^{6}$ uses a more complex three-step approach to
Table 1 Criteria used to clear the cervical spine (C-spine) without imaging

National Emergency X-Radiography Study (NEXUS) criteria for low probability of $C$-spine injury:

1. No midline cervical tenderness

2. No focal neurological deficit

3. Normal level of alertness

4. No evidence of intoxication

5. No painful distracting injury

Patients are required to satisfy all five criteria to be considered lowrisk.

The Canadian C-spine Rule $(C C R)^{7}$

For alert (Glasgow Coma Scale Score $=15$ ) and stable trauma patients. Patients should fulfill all of the following conditions:

1. None of the high-risk factors that mandate radiography should be present.
a. Age $\geq 65 \mathrm{yr}$
b. Dangerous mechanism of injury*
c. Paresthesias in extremities

2. Any of the low-risk factors that allow safe assessment of range of motion (ROM) should be present.
a. Simple rear-end motor vehicle collision (MVC)**
b. Sitting position in emergency department
c. Ambulatory at any time
d. Only delayed onset of neck pain***
e. Absence of midline C-spine tenderness

3. If safe assessment of range of motion allowed, ask patient to rotate neck actively $45^{\circ}$ left and right. No radiography is required if patient is able to rotate neck actively.

\footnotetext{
* Dangerous mechanisms $=$ fall from $\geq 1 \mathrm{~m}$ or five stairs, or axial load to the head (e.g., diving, high speed MVC $>100 \mathrm{~km} \cdot \mathrm{hr}^{-1}$, rollover, ejection, motorized recreational vehicles, bicycle collision)

** Simple rear-end MVC excludes pushed onto ongoing traffic, hit by bus/large truck, rollover, hit by high-speed vehicle

$* * *$ Delayed $=$ not immediate onset of neck pain
} 
determine if further imaging is required in the alert and stable trauma patient. First, the patient should have none of three high-risk factors: age $\geq 65 \mathrm{yr}$, a dangerous mechanism of injury (fall from $\geq 1 \mathrm{~m}$, axial load to the head, high speed motor vehicle accident, rollover or ejection, use of a motorized recreational vehicle, use of a bicycle), or paresthesias in the extremities. Second, the patient should present at least one of the following low-risk factors that allow safe assessment of C-spine range of motion: a simple rear-end motor vehicle accident, ability to assume the sitting position in the emergency department, ambulation at any time, only a delayed onset of neck pain, or no midline $\mathrm{C}$-spine tenderness. Third, the patient should then be able to rotate his neck actively $45^{\circ}$ left and right before cervical immobilization can be lifted. In 2003, the NEXUS and CCR clinical decision rules were compared prospectively in a large study, and the CCR was found to have higher sensitivity and specificity than the NEXUS criteria. ${ }^{7}$ Furthermore, in a recent study, the NEXUS criteria were found to have even lower sensitivity than originally thought. ${ }^{8}$

\section{Moderate- to high-risk patients}

Whichever decision strategy is chosen, a majority of blunt trauma patients will not satisfy the criteria for clearing the $\mathrm{C}$-spine and will require imaging. In these patients, a threeview trauma series consisting of anteroposterior, lateral, and odontoid views was long considered the initial study of choice. However, this test has poor sensitivity, in part because it often visualizes inadequately the craniocervical and cervicothoracic spine, where most injuries tend to occur. Therefore, a normal three-view trauma series is not considered sufficient to rule out C-spine injury, ${ }^{9,10}$ and it is even considered unnecessary by the EAST guidelines. ${ }^{4} \mathrm{~A}$ thin-section computed tomographic (CT) examination of the spine from the occiput to $\mathrm{T} 1$, including sagittal and coronal multiplanar reconstructed images, is now considered the imaging modality of choice. $4,9,10$

The role of magnetic resonance imaging (MRI) is clearly established in evaluating spinal cord injury; therefore, if clinical presentation or CT imaging suggests cord injury in trauma patients, they should undergo MRI, if possible. ${ }^{4,9}$ However, the systematic addition of MRI to CT scanning in the evaluation of all at-risk trauma patients is more controversial. The advantage of MRI is its ability to demonstrate clearly soft tissue injury that could be missed by CT, notably ligamentous injury, especially if it is not associated with fractures. However, MRI is an extremely sensitive study, and the significance of the soft tissue abnormalities it reveals is often unknown, especially in patients with a normal CT scan and no neurological findings. In addition, routine use of MRI would certainly increase costs and expose patients to definite risks that could occur during transfer to the MRI suite or as a result of prolonged immobilization (either while waiting for the MRI to be performed or when confronted with an image of uncertain significance in a patient who cannot be examined neurologically). Use of MRI as a complement to CT scanning is therefore considered an option in two settings, namely, in the neurologically intact awake and alert patient who has a negative CT scan and is complaining of neck pain, and in the obtunded patient with a normal $\mathrm{CT}^{4}$ In the latter situation, the EAST guidelines consider clearing the C-spine without MRI as a valid option (provided there is gross motor function in all four extremities), while others recommend an MRI as a routine supplement to CT scanning in patients not expected to be clinically evaluable within 48 hr. $^{9}$

\section{Immobilization}

Anesthesiologists caring for patients with a potentially injured C-spine will most often need to secure the airway before the $\mathrm{C}$-spine has been properly cleared or before it has been surgically stabilized in the case of injury. These patients will typically have their $\mathrm{C}$-spine immobilized in the neutral position using a rigid cervical collar, sandbags, tape, and a backboard, or a variation thereof, because this combination has been shown to produce the greatest restriction of movement. ${ }^{11}$ Although intuitively appealing and widely recommended, ${ }^{12,13}$ it is important to point out that the practice of immobilizing the potentially injured C-spine to prevent secondary neurological injury has not been studied in a rigorous manner in a population of statistically significant size, and it has never been shown to improve patient outcome. ${ }^{14}$ Furthermore, it should always be kept in mind that immobilization is not devoid of risk. Airway obstruction can occur; intracranial pressure increases, ${ }^{15}$ and if immobilization becomes prolonged, problems tend to develop, e.g., pressure sores, difficult intravenous access and nursing care, and increased nosocomial infections. Despite the uncertainties, it remains unlikely that immobilization will be properly evaluated by randomized controlled trials, and it will remain part of clinical practice in the foreseeable future.

\section{Airway management}

Of particular interest to the anesthesiologist is immobilization during airway management. Since the cervical collar-sandbag-tape-backboard combination hinders airway management independently of its immobilization of the C-spine by severely limiting mouth opening ${ }^{16}$ and restricting access to the patient's neck, it is currently recommended to remove the anterior part of the cervical collar 
with manual in-line stabilization (MILS) of the C-spine. ${ }^{12}$ It is possible to apply MILS by having the assistant stand either at the head of the bed (Fig. 3) or at the side of the bed at the level of the thorax (Fig. 4). When standing at the head of the bed, the assistant grasps the mastoid processes with his/her fingertips and cups the occiput in his/her hands; when standing at the side of the bed, the assistant

\section{MILS from patient's head}

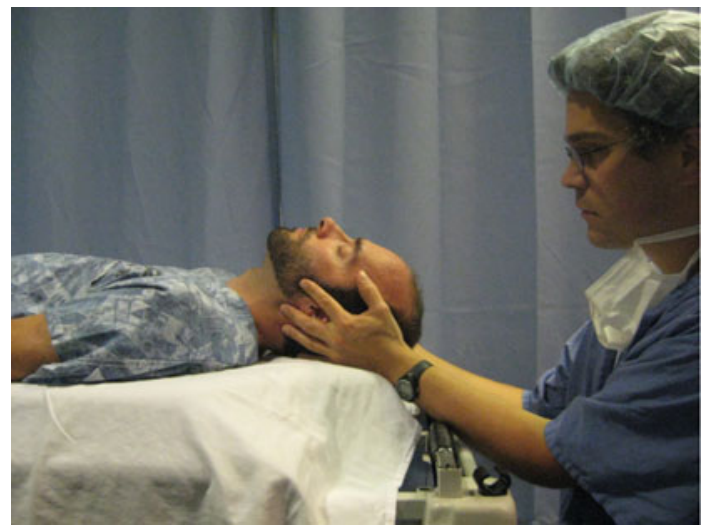

Fig. 3 Manual in-line stabilization (MILS) with the assistant at the head of the bed. The patient's head is held with the assistant's fingertips grasping the mastoids and the assistant's palms cup the occiput. Published with permission

Fig. 3 Stabilisation manuelle en ligne (SMEL), avec l'assistant à la tête du lit. La tête du patient est tenue entre les mains de l'assistant; le bout de ses doigts tient les apophyses mastoïdes et ses paumes se trouvent sous l'occiput du patient. Publié avec permission

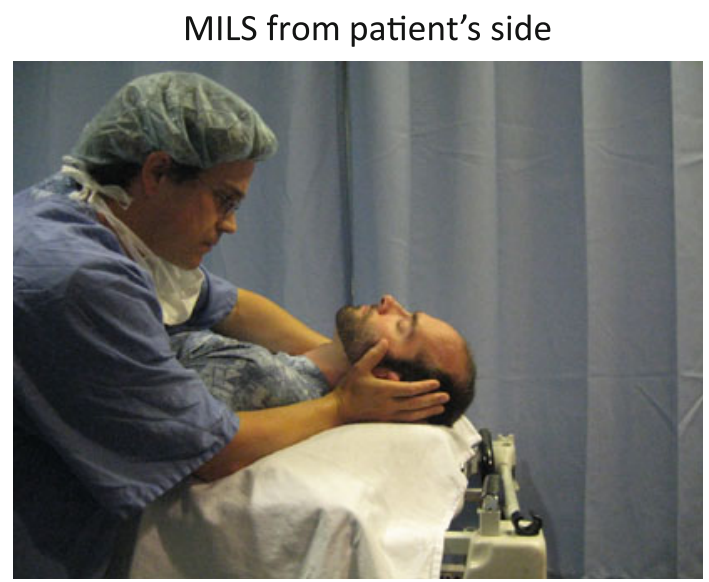

Fig. 4 Manual in-line stabilization (MILS) with the assistant standing at the side of the bed. The patient's head is held with the assistant's palms cupping the mastoids and the assistant's fingertips grabbing both sides of the patient's head. Published with permission Fig. 4 Stabilisation manuelle en ligne (SMEL), avec l'assistant au côté du lit. La tête du patient est tenue entre les mains de l'assistant; ses paumes entourent les apophyses mastoïdes et ses doigts tiennent les deux côtés de la tête du patient. Publié avec permission holds the occiput with his/her fingertips and cups the mastoids with the palms of his/her hands. The assistant providing MILS should apply only the amount of force necessary to counteract the forces exerted by the laryngoscopist without applying axial traction. However, MILS remains somewhat controversial, chiefly because its effect on patient outcome has never been properly studied, and its ability to decrease cervical motion during airway management has been challenged. ${ }^{17}$ It has been clearly established that MILS impairs glottic visualisation, ${ }^{18}$ and it significantly hinders tracheal intubation with direct laryngoscopy, ${ }^{19}$ although not to the same extent as the collarsandbag-tape-backboard combination. ${ }^{20}$

\section{Impact of different airway techniques}

Since much emphasis has been placed historically on the risk of secondary neurological injury from excessive $\mathrm{C}$-spine movement during airway management, there has been abundant literature documenting movement generated by different airway techniques. Herein we provide a partial review (Table 2). A thorough review of the topic can be found elsewhere. ${ }^{21}$

\section{Direct laryngoscopy}

In normal subjects under general anesthesia without MILS, direct laryngoscopy (DL) and tracheal intubation produce extension at each individual vertebral segment. ${ }^{22}$ Most of the movement is concentrated in the occipitoatlantoaxial complex, while the lower C-spine, down to C5 (the last segment visualized with fluoroscopy in many studies), moves only very little. Considered as a whole, however, the $\mathrm{C}$-spine undergoes extension of its rostral portion but flexion of its caudal portion, which is "anchored" by the thorax and pivots around the cervicothoracic junction during laryngoscopy. Amplitude of movement increases throughout the procedure and reaches its maximum during the passage of the endotracheal tube.

\section{Airway maneuvres}

Studies have compared the effect of basic airway maneuvres, such as chin lift, jaw thrust, and mask ventilation, with that of DL. While it was suggested in some older articles that basic airway maneuvres induced greater C-spine movement than DL, ${ }^{23}$ more recent studies with better methodology have shown either comparable ${ }^{24}$ or less movement. ${ }^{25}$ Similarly, the effect of cricoid pressure has been found to be very modest, ${ }^{26}$ at least in the intact C-spine. 
Table 2 Characteristics of different airway techniques in the patient with a potentially injured cervical spine (C-spine)

\begin{tabular}{|c|c|}
\hline Technique & Characteristics \\
\hline Basic airway maneuvres & $\begin{array}{l}\text { C-spine movement is comparable with or } \\
\text { less than direct laryngoscopy. }\end{array}$ \\
\hline \multirow[t]{5}{*}{ Direct laryngoscopy (DL) } & - ease of use \\
\hline & - rapidity \\
\hline & $\begin{array}{l}\text { - fewer concerns for secretions in the } \\
\text { airway }\end{array}$ \\
\hline & $\begin{array}{l}\text { - C-spine movement may be greater than } \\
\text { with alternative techniques, such as the } \\
\text { fibreoptic bronchoscope and the } \\
\text { Trachlight }{ }^{\circledR}\end{array}$ \\
\hline & $\begin{array}{l}\text { - glottic visualization may be limited with } \\
\text { manual in-line stabilization (MILS) }\end{array}$ \\
\hline \multirow[t]{3}{*}{$\begin{array}{l}\text { GlideScope } \\
\text { videolaryngoscope }\end{array}$} & $\begin{array}{l}\text { - C-spine movement similar to direct } \\
\text { laryngoscopy }\end{array}$ \\
\hline & - better glottic visualization \\
\hline & $\begin{array}{l}\text { - takes more time to secure the airway } \\
\text { than with DL }\end{array}$ \\
\hline \multirow[t]{4}{*}{ Trachlight $^{\circledR}$ lighted stylet } & - minimizes C-spine motion \\
\hline & - immune to secretions in the airway \\
\hline & $\begin{array}{l}\text { - can be performed with cervical collar in } \\
\text { place }\end{array}$ \\
\hline & $\begin{array}{l}\text { - contraindicated in patients with airway } \\
\text { trauma or a deformed airway }\end{array}$ \\
\hline \multirow[t]{4}{*}{ Fibreoptic bronchoscope } & $\begin{array}{l}\text { - minimizes C-spine motion in patients } \\
\text { under general anesthesia }\end{array}$ \\
\hline & - preferred technique in the awake patien \\
\hline & $\begin{array}{l}\text { - more difficult and slower to perform } \\
\text { than DL in unconscious }\end{array}$ \\
\hline & $\begin{array}{l}\text { patients and in patients with blood or } \\
\text { secretions in the airway }\end{array}$ \\
\hline \multirow[t]{2}{*}{$\begin{array}{l}\text { Laryngeal mask airway } \\
\text { device }\end{array}$} & $\begin{array}{l}\text { - movement similar to direct } \\
\text { laryngoscopy }\end{array}$ \\
\hline & $\begin{array}{l}\text { - relatively contraindicated in patients } \\
\text { with a full stomach }\end{array}$ \\
\hline
\end{tabular}

Newer airway techniques

In addition to DL, Brimacombe $e t a l .{ }^{24}$ studied the impact of four airway techniques (laryngeal mask airway device [LMAD], nasal fibreoptic intubation, tracheoesophageal Combitube $^{\circledR}$, and fibreoptic intubation via an intubating LMAD) using a cadaver model with posterior C3 instability and undergoing MILS. They found that only nasal intubation over a fibreoptic bronchoscope produced no significant movement, and insertion of a Combitube ${ }^{\circledR}$ produced the most movement. Turkstra et $a .^{25}$ more recently compared the effects of DL, the Trachlight ${ }^{\circledR}$ luminous intubating stylet, and the GlideScope ${ }^{\circledR}$ videolaryngoscopy with the effects of $\mathrm{C}$-spine stabilization in normal subjects under general anesthesia. While the Trachlight ${ }^{\circledR}$ reduced movement by about half compared with DL, GlideScope ${ }^{\circledR}$ videolaryngoscopy offered no clinically significant reduction in movement, a finding confirmed in another study. ${ }^{27}$ The Trachlight ${ }^{\circledR}$ has also been shown to induce as little movement as fibreoptic intubation in patients under general anesthesia. ${ }^{28}$

\section{Limitations of studies}

With new airway devices being introduced regularly into clinical practice, similar studies comparing newer with more established techniques continue to be added to the literature. It is nevertheless important to bear in mind that such studies have limitations. One important limitation is the absence of a clearly established threshold defining dangerous C-spine movement. ${ }^{29}$ It can therefore be difficult to determine if a statistically significant movement in one study is truly clinically significant. In addition, what is clinically significant might actually vary from one patient to another since other dynamic factors, such as hemodynamic instability and tissue edema, come into play to compound the mechanical effect of $\mathrm{C}$-spine motion on damaged neurological tissue. ${ }^{30}$ Furthermore, most studies are performed on subjects with an intact $\mathrm{C}$-spine or on cadavers with one standardized type of injury. Generalizing findings from these studies to the heterogeneous population of real-life patients with C-spine injury remains difficult, as is the comparison of results obtained by studies where different injury models or different methodologies have been used.

\section{Outcome}

An additional limitation inherent in this literature is its exclusive focus on quantifying $\mathrm{C}$-spine movement, a surrogate endpoint which is only one of many factors potentially affecting clinical outcome in patients with $\mathrm{C}$-spine injury. Since the choice of airway technique might influence other important determinants of clinical outcome, such as duration of hypoxemia and hemodynamic instability, studies comparing the effect of different techniques on clinical endpoints, such a neurological outcome, would be more desirable. However, because it is difficult to conduct methodologically robust studies dealing with this question, case reports and case series, with their inherent limitations, must be relied on to assess the impact of airway management on the neurological outcome of patients with C-spine instability.

Despite airway management in patients with $\mathrm{C}$-spine instability being a relatively common clinical occurrence, the actual number of cases where it has been alleged to have caused neurological deterioration is small, and in many of those cases, the causal link between both is tenuous. ${ }^{30}$ Furthermore, many case series involving moderate numbers of patients with unstable $\mathrm{C}$-spines who underwent airway management, often DL under general anesthesia, reported no neurological deterioration after intubation. ${ }^{31,32}$ 
Although these studies can suffer from reporting bias and may lack adequate power to detect rare events, as a whole, they suggest that the risk of causing secondary neurological damage when securing the airway might be smaller than originally perceived. ${ }^{30} \mathrm{~A}$ recent review of the American Society of Anesthesiologists' Closed Claims Project database revealed that most incidents of anesthesia-related C-spine injury did not occur in trauma patients but rather in healthy patients who underwent elective non-trauma surgery and appeared to have stable C-spines. ${ }^{33}$

\section{Other considerations}

Such an assessment of the literature should encourage anesthesiologists to broaden their perspective when dealing with a patient with potential C-spine instability. Minimizing C-spine movement is important, but rapidly and effectively securing the airway is also crucial in many nonelective situations. Hypoxemia and hypercarbia caused by an unsecured airway or by protracted airway manipulations are especially deleterious in patients with neurological injury and should be avoided at all cost.

\section{Choice of airway technique}

Each airway device offers its own advantages and disadvantages, and the most appropriate choice will often depend on practitioner experience with a particular technique and the specific clinical situation. For example, the fibreoptic bronchoscope provides great $\mathrm{C}$-spine stability in competent hands with a cooperative and adequately prepared patient, but it is often ill-suited in the context of trauma because patients often are uncooperative, have blood and secretions in the airway making both airway preparation and visualization difficult, and require rapid securing of their airway. On the other hand, DL is associated with slightly more $\mathrm{C}$-spine movement and might be more difficult with $\mathrm{C}$-spine immobilization, but it offers speed and convenience with less concern for airway secretions or blood. Finally, videolaryngoscopy offers better glottic visualization than DL in the presence of MILS, ${ }^{27}$ but it generally takes more time to accomplish. $^{25}$

\section{Summary and conclusions}

Optimally managing the airway in the face of potential $\mathrm{C}$-spine instability requires knowledge of basic $\mathrm{C}$-spine anatomy and an understanding of how to assess stability, immobilize the $\mathrm{C}$-spine, and select an appropriate airway technique. In terms of clinical evaluation and imaging, strong recommendations can be made based on evidencebased guidelines:
1. History and physical examination are sufficient to clear the C-spine in low-risk blunt trauma patients who meet the criteria of the NEXUS trial or those of the CCR; and

2. A thin-section CT scan from occiput to $\mathrm{T} 1$ is mandatory in all other high-risk patients.

Concerning immobilization, recommendations are consistent, but they rely on scant evidence and the recommended techniques have drawbacks:

1. A rigid cervical collar, sandbags, tape, and a backboard, or a variation thereof, should be used to immobilize the $\mathrm{C}$-spine of trauma patients, and the practitioner should strive to clear the $\mathrm{C}$-spine rapidly to avoid the complications of prolonged immobilization; and

2. Since the standard immobilization technique severely impairs airway management, the anterior portion of the hard collar should be removed and MILS should be applied when securing the airway, keeping in mind that DL will likely be more difficult in this context.

No guideline exists regarding the choice of airway technique. Based on case reports and case series, currently employed techniques appear somewhat safer than previously thought. While minimizing $\mathrm{C}$-spine motion remains an important objective, other goals mandated by specific clinical situations, such as rapidly and effectively securing the airway to prevent hypoxia and hypercarbia, should not be neglected. Different techniques offer different benefits and limitations, and therefore selection should be based on the specific clinical situation and on the experience of the practitioner.

\section{Clinical case scenario}

A 25-yr-old man is brought to the emergency room after he crashed his car into a large tree when he was returning home after a night out with friends. Upon arrival, he is oriented, denies any neck pain, but complains of severe abdominal tenderness. He becomes progressively more confused and agitated as his blood pressure starts to decrease despite aggressive fluid resuscitation. He has a muscular build, and he is $1.85 \mathrm{~m}$ tall and weighs $100 \mathrm{~kg}$. His pulse is 123 beats. $\min ^{-1}$, blood pressure 93/ $51 \mathrm{mmHg}$, and oxygen saturation (SpO2) 97\% while being administered $100 \% \mathrm{O}_{2}$ by mask. The patient's mouth opening is difficult to assess since he is now uncooperative, and there appears to be some blood in the airway. The thyromental distance is normal and the patient's neck is short and stocky. Air entry is equal bilaterally, and Focused Assessment with Sonography in Trauma (FAST) ultrasound is positive for intra-abdominal fluid. 
Instructions for completing the continuing professional development (CPD) module

1. Read the current article and the references indicated in bold.

2. Go to: https://www.cpass2.umontreal.ca/selfassessment program/ and select the current module (Airway management in the patient with potential cervical spine instability).

3. Answer the multiple choice questions regarding the case scenario.

4. Once you have entered all of your answers, you will have access to experts' explanations for all the possible choices.

5. Participants may claim up to four hours of CPD for a total of 12 credits under Section 3 of the CPD program of the Royal College of Physicians and Surgeons of Canada.

\section{La prise en charge des voies aériennes chez le patient présentant une instabilité potentielle de la colonne cervicale}

\author{
Résumé \\ Objectif La prise en charge des voies aériennes chez un \\ patient présentant une colonne cervicale potentiellement \\ instable est une tâche complexe. L'objectif de ce module de \\ développement professionnel continu est de passer en \\ revue les connaissances actuelles essentielles à la prise en \\ charge des voies aériennes dans les cas d'instabilité \\ potentielle de la colonne cervicale, tout en soulignant les \\ zones d'incertitude et les limites de la littérature existante. \\ Constatations principales Chez les patients à faible \\ risque, définis à l'aide de critères rigoureux obtenus \\ d'études multicentriques d'envergure, la colonne cervicale \\ peut être considérée comme stable, ou 'normale', sans \\ avoir recours à l'imagerie. Chez tous les autres patients, il \\ convient de réaliser au minimum un examen par \\ tomodensitométrie en tranches minces de la colonne entre \\ l'occiput et T1, comprenant des images reconstituées de \\ plans sagittaux et frontaux multiples. Jusqu'à ce qu'on ait \\ confirmé la stabilité de la colonne cervicale, celle-ci \\ devrait être immobilisée en position neutre à l'aide d'un \\ collet cervical rigide, de sacs de sable, de ruban adhésif et \\ d'une planche dorsale. Pendant la prise en charge des \\ voies aériennes, la partie antérieure du collet cervical
}

devrait être retirée et une stabilisation manuelle en ligne appliquée. Il a été démontré que certaines techniques de prise en charge des voies aériennes, comme la bronchoscopie à fibre optique et le Trachlight ${ }^{\circledR}$, induisaient moins de mouvement au niveau de la colonne cervicale que la laryngoscopie directe; toutefois, l'impact de telles mesures de prise en charge des voies aériennes sur le pronostic des patients est inconnu.

Conclusion Une prise en charge des voies aériennes adaptée du patient présentant une lésion potentielle de la colonne cervicale exige une compréhension de l'anatomie de la colonne cervicale, des critères d'évaluation de la stabilité de la colonne cervicale, et des indications, techniques et pièges de l'immobilisation de la colonne cervicale. Le choix d'une technique de prise en charge des voies aériennes devrait tenir compte de la minimisation de la mobilité de la colonne cervicale, mais devrait également porter attention au contexte clinique dans son ensemble.

\section{Objectifs de ce module de développement professionnel continu (DPC)}

Après avoir lu ce module, le lecteur devrait être en mesure de:

1) Posséder une connaissance de base de l'anatomie et de la biomécanique de la colonne cervicale.

2) Comprendre comment évaluer la stabilité de la colonne cervicale de façon clinique et radiologique.

3) Évaluer l'efficacité, les avantages et les risques des manœuvres de stabilisation.

4) Évaluer l'impact de différentes techniques de prise en charge des voies aériennes, en termes de mouvement de la colonne cervicale et de pronostic clinique.

\section{Synthèse}

La prise en charge des voies aériennes chez un patient pouvant être atteint d'une instabilité de la colonne cervicale est une tâche difficile. En effet, l'anesthésiologiste doit gérer simultanément deux objectifs importants mais potentiellement concurrents, à savoir la minimisation du mouvement de la colonne cervicale afin de prévenir toute détérioration neurologique, et la prise en charge sécuritaire et efficace des voies aériennes du patient. Le choix du plan d'action optimal est encore compliqué par nos connaissances incomplètes de la relation entre les différentes techniques de prise en charge des voies aériennes, le mouvement de la colonne cervicale qu'elles produisent, les lésions de la moelle épinière, et le devenir du patient. 
On parle d'instabilité de la colonne cervicale lorsque des forces physiologiques sur la colonne atteinte provoquent certains types de déplacement vertébral qui mettent en péril la moelle épinière ou les racines nerveuses. ${ }^{1}$ L'instabilité de la colonne cervicale est le plus souvent associée à un traumatisme. Toutefois, elle peut aussi découler d'autres mécanismes, comme par exemple d'une anomalie congénitale, d'une inflammation systémique, d'une tumeur ou d'une infection. La prise en charge des voies aériennes des patients présentant une instabilité potentielle de la colonne cervicale peut être nécessaire en raison d'une instabilité respiratoire ou hémodynamique, ou en raison d'une intervention urgente ou réglée sous anesthésie générale.

Dans cet article, nous passerons brièvement en revue les connaissances actuelles essentielles à la prise en charge des voies aériennes dans les cas d'instabilité potentielle de la colonne cervicale, tout en soulignant les zones d'incertitude et les limites de la littérature existante.

\section{Anatomie et biomécanique de la colonne cervicale}

La colonne cervicale se compose de la base du crâne et de sept vertèbres cervicales (figures 1 et 2). Sa portion inférieure (C3-C7) comprend cinq vertèbres semblables d'un point de vue anatomique à leurs pendants thoraciques et lombaires, hormis la présence de foramens transverses bilatéraux à travers lesquels les artères vertébrales montent. Sa partie supérieure, le complexe occipito-atlanto-axial, comporte trois éléments osseux possédant des caractéristiques anatomiques distinctes: la base du crâne (occiput); l'atlas (C1), une vertèbre en forme d'anneau ne possédant pas de corps vertébral ni d'apophyse épineuse; et l'axis (C2), caractérisé par son apophyse odontoïde (ou dent), un prolongement vers le haut de son corps vertébral, qui fait saillie dans l'anneau de $\mathrm{C} 1$.

La structure osseuse de la colonne cervicale est stabilisée par les disques vertébraux, les facettes vertébrales, les muscles paravertébraux et de nombreux ligaments. Le ligament transverse attache l'apophyse odontoïde à la surface postérieure de l'arc antérieur de C1. Les ligaments apical et alaire vont de l'apophyse odontoïde aux limites antérieures du foramen magnum à la base du crâne. Les ligaments épineux antérieurs et postérieurs remontent sur les surfaces antérieures et postérieures, respectivement, des corps vertébraux. Le ligament jaune connecte les laminas adjacentes. Enfin, les ligaments inter- et supra-épineux attachent les apophyses épineuses ensemble. Dans le canal rachidien, la moelle épinière est séparée des éléments osseux et ligamenteux par l'espace sous-arachnoïdien, lequel est rempli de liquide céphalorachidien.
La colonne cervicale est mobile sur trois axes (flexion/ extension, rotation, et mouvement latéral); toutefois, les manipulations au niveau des voies aériennes impliquent presque exclusivement les mouvements de flexion et d'extension. Le mouvement n'est pas distribué de façon uniforme le long de la colonne cervicale ${ }^{2}$ : l'articulation occiput-C1 permet environ $15-20^{\circ}$ d'extension mais seulement $5^{\circ}$ de flexion, alors que $\mathrm{C} 1-\mathrm{C} 2$, l'articulation la plus importante pour la rotation axiale, permet environ $10^{\circ}$ de flexion et d'extension; la colonne cervicale inférieure permet d'atteindre encore environ $65^{\circ}$ de plus de flexion ou d'extension, la plus grande partie de cette souplesse étant imputable aux segments caudaux.

\section{Évaluation de la stabilité de la colonne cervicale}

Il est difficile de déterminer si la colonne cervicale d'un patient est stable ou non; cette évaluation comporte de nombreuses conséquences, pour le patient autant que d'un point de vue médico-légal. Bien qu'en règle générale il ne devrait pas incomber aux anesthésiologistes de déterminer la stabilité de la colonne cervicale, ils doivent néanmoins comprendre la façon de procéder pour évaluer la stabilité de la colonne cervicale et, en raison des conséquences des lésions négligées, ils devraient rester sur le qui-vive quant à une possible instabilité de la colonne cervicale. ${ }^{3}$ Étant donné que la majeure partie de la littérature portant sur l'évaluation de la colonne cervicale est tirée de contextes de traumatisme, nous limiterons notre discussion aux patients de traumatologie. Nombre de ces principes peuvent toutefois également s'appliquer aux patients se présentant avec d'autres anomalies, qu'elles soient de nature congénitale, maligne, inflammatoire, infectieuse ou dégénérative.

L'évaluation de la stabilité de la colonne cervicale s'appuie en général sur un ensemble de critères comprenant les antécédents médicaux, un examen physique et des examens radiologiques. Les directives les plus récentes à ce sujet ont été récemment mises à jour par l'Eastern Association for the Surgery of Trauma américaine (EAST). ${ }^{4}$

\section{Patients à faible risque}

Le questionnaire et l'examen physique constituent la base de la stratification initiale des patients présentant potentiellement une instabilité de la colonne cervicale; cela permet de déterminer si des examens radiologiques sont indiqués. Chez une minorité de patients, soit les personnes présentant une probabilité très faible de lésion majeure, il est possible de confirmer la stabilité de la colonne cervicale sans procéder à des radiographies. Deux stratégies ont été testées dans des études multicentriques d'envergure portant sur des milliers de patients de traumatologie pour identifier 
ces patients à faible risque (tableau 1). Selon l'approche simple du groupe NEXUS (National Emergency $X$-Radiography Study Group), ${ }^{5}$ il est raisonnable de présumer que la colonne cervicale est stable sans imagerie chez un patient adulte ayant un traumatisme contondant et ne présentant aucune sensibilité de la ligne médiane de la colonne cervicale, aucun déficit neurologique focal, une vigilance intellectuelle normale, aucune intoxication et aucune lésion douloureuse le préoccupant. Cette stratégie est également appuyée par les directives de l'EAST. ${ }^{4}$ Une autre stratégie, la règle canadienne de la colonne cervicale (Canadian C-Spine Rule, ou CCR), ${ }^{6}$ utilise une approche plus complexe en trois points afin de déterminer si des examens radiologiques plus poussés sont nécessaires chez un patient traumatisé alerte et stable. En premier lieu, le patient ne doit présenter aucun de ces trois facteurs de risque élevé: un âge $\geq 65$ ans, un mécanisme de lésion dangereux (chute de $\geq 1 \mathrm{~m}$, charge axiale à la tête, accident de véhicule motorisé à grande vitesse, capotage ou éjection, utilisation d'un véhicule récréatif motorisé, utilisation d'une bicyclette), ou des paresthésies dans les membres. Deuxièmement, le patient doit présenter au moins l'un des facteurs de risque faible suivants, qui permettent d'évaluer en toute sécurité l'amplitude de mouvement de la colonne cervicale: une collision arrière simple dans un véhicule motorisé, la position assise à l'urgence, l'ambulation à n'importe quel moment, une douleur au cou n'apparaissant que tardivement, et aucune sensibilité à la ligne médiane de la colonne cervicale. Troisièmement, le patient devrait ensuite être capable de tourner la tête activement de $45^{\circ}$ vers la gauche et vers la droite avant de retirer le collet d'immobilisation cervicale. En 2003, une étude a comparé les règles de décision clinique NEXUS et CCR dans un vaste essai prospectif, et il a été déterminé que les critères du CCR avaient une meilleure sensibilité et une meilleure spécificité que ceux du NEXUS. ${ }^{7}$ En outre, dans une étude récente, on a observé que les critères NEXUS avaient une sensibilité encore plus basse que ce qu'on pensait à l'origine. ${ }^{8}$

\section{Patients à risque modéré à élevé}

Quelle que soit la règle préférée pour confirmer la stabilité de la colonne cervicale, la plupart des patients souffrant de traumatisme contondant ne répondront pas aux critères permettant d'écarter tout risque de lésion de la colonne cervicale et nécessiteront par conséquent des examens radiologiques. Pendant longtemps, l'examen initial de choix chez ces patients a consisté en une série de traumatologie en trois plans composée d'une vue antéro-postérieure, d'une vue latérale et d'une vue odontoïde. Cet examen affiche néanmoins une mauvaise sensibilité, en partie parce qu'il visualise souvent de façon inadéquate la colonne
Tableau 1 Critères pour confirmer la stabilité de la colonne cervicale sans examen radiologique

Critères NEXUS (National Emergency X-Radiography Study) de probabilité faible de lésion à la colonne cervicale ${ }^{5}$

1. aucune sensibilité à la ligne médiane cervicale

2. aucun déficit neurologique focal

3. vigilance normale

4. aucune intoxication

5. aucune lésion douloureuse préoccupant le patient

Les patients doivent satisfaire aux cinq critères pour être considérés comme présentant un risque faible.

La règle canadienne de la colonne cervicale $(C C R)^{7}$

Pour les patients de traumatologie alertes (Score sur l'échelle de coma de Glasgow $=15$ ) et stables, les patients doivent remplir toutes les conditions ci-dessous:

1. Aucun des facteurs de risque élevé qui requiert une radiographie a. Âge $\geq 65$ ans

b. Mécanisme de lésion dangereux*

c. Paresthésies dans les membres

2. Au moins un des facteurs de risque faible qui permettent une évaluation sécuritaire de l'amplitude de mouvement (ADM)?

a. Collision arrière simple dans un véhicule motorisé**

b. Position assise au département de l'urgence

c. Ambulation à n'importe quel moment

d. Douleur au cou apparaissant que tardivement***

e. Absence de sensibilité à la ligne médiane de la colonne cervicale

3. Si on peut évaluer l'amplitude de mouvement de façon sécuritaire, demander au patient de tourner activement la tête de $45^{\circ}$ vers la gauche et vers la droite. Aucune radiographie n'est nécessaire si le patient peut activement tourner son cou.

* Mécanismes dangereux: chute de $\geq 1 \mathrm{~m}$ ou cinq marches; ou charge axiale à la tête, par ex. en plongée; collision de véhicule motorisé à haute vitesse $\left(>100 \mathrm{~km} \cdot \mathrm{h}^{-1}\right)$; capotage, éjection; véhicules récréatifs motorisés; collision à bicyclette

** Les collisions arrière simples excluent: être poussé dans le sens contraire de la circulation; être happé par un bus / gros camion; le capotage; être frappé par un véhicule à haute vitesse

*** Tardivement: début non immédiat de la douleur au cou

crânio-cervicale et cervico-thoracique, là où surviennent la plupart des lésions. Par conséquent, une série de traumatologie normale en trois plans n'est pas considérée comme suffisante pour confirmer l'absence de lésion à la colonne cervicale ${ }^{9,10}$; cet examen est même considéré comme non indispensable par les directives de l'EAST. ${ }^{14}$ Un examen par tomodensitométrie en tranches minces de la colonne, de l'occiput à T1, qui inclut des images reconstituées de plans sagittaux et frontaux multiples, est désormais considéré comme la modalité d'imagerie de choix. ${ }^{4,9,10}$

Le rôle de l'imagerie par résonance magnétique (IRM) a été clairement établi pour évaluer les lésions de la moelle épinière; par conséquent, les patients traumatisés chez 
lesquels on soupçonne une lésion de la moelle épinière en raison de la présentation clinique ou des radiographies devraient, dans la mesure du possible, subir une IRM. ${ }^{4,9}$ L'ajout systématique de l'IRM à la tomodensitométrie pour l'évaluation de tous les patients traumatisés à risque demeure toutefois plus controversé. L'avantage de l'IRM réside dans sa capacité à montrer directement des lésions des tissus mous que la tomodensitométrie pourrait ne pas détecter, notamment les lésions ligamenteuses, tout particulièrement si la lésion n'est pas associée à une fracture. En revanche, l'IRM est un examen extrêmement sensible, et la gravité des anomalies des tissus mous ainsi révélés est souvent inconnue, particulièrement chez les patients dont les examens tomodensitométriques étaient normaux et qui ne présentent pas de symptômes neurologiques. De plus, l'utilisation systématique de l'IRM augmenterait indubitablement les coûts et exposerait les patients à des risques certains, par exemple ceux qui peuvent survenir pendant le transfert à la salle d'IRM, ou suite à une immobilisation prolongée (soit pendant l'attente avant de subir l'IRM ou lorsque l'interprétation d'une image est ambiguë chez un patient pour qui l'examen neurologique est impossible à réaliser). Par conséquent, l'utilisation de l'IRM en complément de la tomodensitométrie est considérée une option thérapeutique dans deux cas de figure: chez un patient éveillé, alerte et sans lésion neurologique se plaignant de douleur au cou et dont l'examen tomodensitométrique est négatif, et chez un patient inconscient dont l'examen tomodensitométrique est normal. ${ }^{4}$ Il est à noter que dans le deuxième cas de figure, selon les directives de l'EAST, l'évaluation de la colonne cervicale peut également se faire sans IRM (s'il y a une fonction motrice globale dans les quatre membres), alors que les autres directives recommandent de réaliser une IRM comme ajout systématique à la tomodensitométrie chez les patients chez qui une évaluation clinique n'est pas anticipée comme étant possible dans les $48 \mathrm{~h}^{9}{ }^{9}$

\section{Immobilisation}

Les anesthésiologistes qui prennent soin de patients présentant une lésion potentielle de la colonne cervicale devront la plupart du temps prendre en charge les voies aériennes avant de savoir si la colonne cervicale est stable ou non, ou avant qu'elle soit stabilisée de façon chirurgicale en cas de lésion. En général, la colonne cervicale de ces patients sera immobilisée en position neutre à l'aide d'un collet cervical, de sacs de sable, de ruban adhésif et d'une planche dorsale, ou d'une variante de ces éléments. En effet, il a été démontré que cette combinaison entraînait la restriction de mouvement la plus importante. ${ }^{11}$ Il faut souligner que la pratique qui consiste à immobiliser une colonne cervicale potentiellement blessée afin de prévenir les lésions neurologiques secondaires, bien qu'instinctivement séduisante et largement recommandée, n'a pas été étudiée de façon rigoureuse chez une population d'envergure statistiquement significative. En outre, il n'a jamais été démontré que cette pratique améliorait le pronostic des patients. ${ }^{14}$ En outre, il faut toujours garder à l'esprit que l'immobilisation comporte elle aussi des risques: il peut y avoir obstruction des voies aériennes, la pression intracrânienne augmente ${ }^{15}$ et, si l'immobilisation est prolongée, des problèmes, tels que des points de pression, un accès intraveineux et des soins infirmiers difficiles, ou encore des infections nosocomiales plus importantes, ont tendance à apparaître. Toutefois, malgré ces incertitudes, il demeure peu probable que l'immobilisation soit évaluée de façon adéquate par des études randomisées contrôlées, et cette pratique restera dans les gestes cliniques dans un avenir prévisible.

Prise en charge des voies aériennes

L'immobilisation pendant la prise en charge des voies aériennes revêt un intérêt particulier pour l'anesthésiologiste. Parce que la combinaison collet cervical / sacs de sable / ruban adhésif / planche dorsale entrave la prise en charge des voies aériennes indépendamment de son immobilisation de la colonne cervicale en limitant dramatiquement l'ouverture de la bouche et en restreignant l'accès au cou du patient, le retrait de la partie antérieure du collet cervical accompagné d'une stabilisation manuelle en ligne (SMEL) de la colonne cervicale est actuellement recommandé. ${ }^{12} \mathrm{Il}$ est possible de réaliser une SMEL avec l'assistant debout soit à la tête du lit (figure 3), ou à côté du lit, au niveau du thorax (figure 4). Lorsqu'il est à la tête du lit, l'assistant saisit les apophyses mastoïdes du bout des doigts et entoure l'occiput de ses mains; lorsque la manœuvre se fait depuis le côté du lit, l'assistant tient l'occiput de ses doigts et entoure les apophyses mastoïdes des paumes. L'assistant fournissant une SMEL ne devrait utiliser que la force nécessaire à contrecarrer les forces exercées par la personne utilisant le laryngoscope, et ne pas appliquer de traction axiale. La SMEL demeure néanmoins quelque peu controversée, principalement parce que son effet sur le pronostic des patients n'a jamais été explicitement étudié et parce que sa capacité à réduire les mouvements cervicaux pendant la prise en charge des voies aériennes a été mise en doute. ${ }^{17}$ Il n'en demeure pas moins qu'il a été clairement établi que la visualisation glottique était gênée par une SMEL et que celle-ci entrave considérablement l'intubation trachéale par laryngoscopie directe (LD) - mais pas autant que la combinaison collet / sac de sable / ruban adhésif / planche dorsale. ${ }^{20}$ 
Impact des différentes techniques de prise en charge des voies aériennes

En raison de l'attention portée dans le passé au risque de lésion neurologique secondaire provoquée par des mouvements excessifs de la colonne cervicale pendant la prise en charge des voies aériennes, le mouvement produit par différentes techniques de prise en charge des voies aériennes a fait l'objet de plusieurs études. Nous les passons en revue partiellement ici (tableau 2); il existe un compte-rendu plus fouillé sur le sujet dans un autre article. ${ }^{21}$

\section{La laryngoscopie directe}

Chez les sujets normaux sous anesthésie générale sans SMEL, la LD et l'intubation trachéale provoquent une extension au niveau de chaque segment vertébral. ${ }^{22} \mathrm{La}$ majeure partie des mouvements se concentre au niveau du complexe occipito-atlanto-axial, alors que la colonne cervicale inférieure, jusqu'à C5 (le dernier segment visualisé par fluoroscopie dans de nombreuses études), ne bouge que très peu. Dans son ensemble toutefois, la colonne cervicale subit une extension de sa partie rostrale mais une flexion de sa partie caudale, qui est 'ancrée' par le thorax et pivote autour de la jonction cervico-thoracique pendant la laryngoscopie. L'amplitude de mouvement augmente tout au long de l'intervention et atteint son maximum pendant le passage de la sonde endotrachéale.

Les manœuvres au niveau des voies aériennes

Des études ont comparé l'effet de manœuvres de base des voies aériennes, comme relever le menton, pousser la mâchoire et ventiler au masque, à la LD. Alors que certains articles plus anciens indiquaient que ces manœuvres de base entraînaient davantage de mouvement de la colonne cervicale que la $\mathrm{LD},{ }^{23}$ des études plus récentes réalisées avec une meilleure méthodologie ont montré que le mouvement était soit comparable, ${ }^{24}$ soit moindre. ${ }^{25}$ De la même manière, il a été observé que l'effet de la pression cricoïdienne était très modeste, à tout le moins sur une colonne cervicale intacte.

Techniques de prise en charge des voies aériennes plus récentes

L'impact de quatre techniques de prise en charge des voies aériennes (c.-à-d. masque laryngé [LMA], intubation nasale par fibre optique, Combitube ${ }^{\circledR}$ trachéo-œsophagien et intubation par fibre optique via un LMA d'intubation) ajoutées à la LD a été étudié par Brimacombe et coll. ${ }^{24}$ sur un modèle cadavérique avec une instabilité postérieure à C3 et subissant une SMEL. Les auteurs ont découvert que
Tableau 2 Caractéristiques des différentes techniques de prise en charge des voies aériennes chez le patient dont la colonne cervicale est potentiellement atteinte

\begin{tabular}{|c|c|}
\hline Technique & Caractéristiques \\
\hline $\begin{array}{l}\text { Manœuvres de base des } \\
\text { voies aériennes }\end{array}$ & $\begin{array}{l}\text { Le mouvement de la colonne cervicale est } \\
\text { comparable ou moindre par rapport à la } \\
\text { laryngoscopie directe }\end{array}$ \\
\hline $\begin{array}{l}\text { Laryngoscopie directe } \\
\text { (LD) }\end{array}$ & $\begin{array}{l}\text { - facilité d'utilisation } \\
\text { - rapidité } \\
\text { - moins d'inquiétudes quant à la présence } \\
\text { de sécrétions dans les voies aériennes } \\
\text { - la colonne cervicale pourrait bouger plus } \\
\text { qu'avec d'autres techniques telles que le } \\
\text { bronchoscope à fibre optique et le } \\
\text { Trachlight }{ }^{\circledR} \\
\text { - la visualisation glottique pourrait être } \\
\text { limitée si on a recours à une stabilisation } \\
\text { manuelle en ligne (SMEL) }\end{array}$ \\
\hline $\begin{array}{l}\text { Vidéolaryngoscope } \\
\text { GlideScope }\end{array}$ & $\begin{array}{l}\text { - mouvement de la colonne cervicale } \\
\text { semblable à celui observé avec la LD } \\
\text { - meilleure visualisation glottique } \\
\text { - il faut plus de temps pour sécuriser les } \\
\text { voies aériennes qu'avec la LD }\end{array}$ \\
\hline $\begin{array}{l}\text { Mandrin lumineux } \\
\text { Trachlight }^{\circledR}\end{array}$ & $\begin{array}{l}\text { - minimise le mouvement de la colonne } \\
\text { cervicale } \\
\text { - indifférent aux sécrétions dans les voies } \\
\text { aériennes } \\
\text { - peut être réalisé avec un collet cervical en } \\
\text { place } \\
\text { - contre-indiqué chez les patients avec un } \\
\text { traumatisme des voies aériennes ou des } \\
\text { voies aériennes déformées }\end{array}$ \\
\hline $\begin{array}{l}\text { Bronchoscope à fibre } \\
\text { optique }\end{array}$ & $\begin{array}{l}\text { - minimise le mouvement de la colonne } \\
\text { cervicale chez les patients sous } \\
\text { anesthésie générale } \\
\text { - technique préférée chez le patient éveillé } \\
\text { - plus difficile et plus lente à réaliser que la } \\
\text { LD chez les patients inconscients et chez } \\
\text { les patients avec du sang et des } \\
\text { sécrétions dans les voies aériennes }\end{array}$ \\
\hline Masques laryngés & $\begin{array}{l}\text { - mouvement de la colonne cervicale } \\
\text { semblable à celui observé avec la LD } \\
\text { - relativement contre-indiqué chez les } \\
\text { patients avec un estomac plein }\end{array}$ \\
\hline
\end{tabular}

seule l'intubation nasale avec un bronchoscope à fibre optique ne produisait pas de mouvement significatif, et que c'était le Combitube ${ }^{\circledR}$ qui provoquait le plus de mouvement. Plus récemment, Turkstra et coll. ${ }^{25}$ ont comparé l'effet de la LD, d'un mandrin d'intubation lumineux Trachlight ${ }^{\circledR}$ et d'une vidéolaryngoscopie avec GlideScope $^{\circledR}$ chez des sujets normaux sous anesthésie générale avec une stabilisation de la colonne cervicale. Alors que la technique avec Trachlight ${ }^{\circledR}$ réduisait environ de moitié le mouvement par rapport à la LD, la 
vidéolaryngoscopie n'a pas permis de réduction de mouvement cliniquement significative, une observation qui a été confirmée par une autre étude. ${ }^{27} \mathrm{Il}$ a également été démontré que la technique avec un Trachlight ${ }^{\circledR}$ produisait aussi peu de mouvement que l'intubation par fibre optique chez des patients sous anesthésie générale. ${ }^{28}$

\section{Limites des études}

En raison de l'introduction constante de nouveaux dispositifs de prise en charge des voies aériennes dans la pratique clinique, des études semblables continuent de s'ajouter à la littérature, études qui comparent des techniques plus récentes à des techniques plus établies. Il est cependant important de garder à l'esprit que de telles études ont toutes des limites. Une limite importante est qu'il n'y a pas de seuil clairement établi définissant un mouvement dangereux de la colonne cervicale. ${ }^{29}$ Dès lors, il peut être difficile de déterminer si un mouvement significatif d'un point de vue statistique dans une étude est véritablement significatif d'un point de vue clinique. De plus, ce qui est significatif d'un point de vue clinique peut en fait varier d'un patient à un autre, étant donné que d'autres facteurs dynamiques comme l'instabilité hémodynamique et l'œdème tissulaire entrent en jeu pour magnifier l'effet mécanique du mouvement de la colonne cervicale sur un tissu neurologique endommagé. ${ }^{30}$ En outre, la plupart des études sont réalisées avec des personnes dont la colonne cervicale est intacte ou sur des cadavres présentant un type normalisé de lésion. L'application généralisée des observations de ces études à la population hétérogène de patients réels présentant une lésion de la colonne cervicale demeure difficile, tout comme la comparaison de résultats obtenus dans des études où différents modèles de lésion ou différentes méthodologies ont été utilisés.

\section{Le pronostic}

Une autre limite inhérente à cette littérature est qu'elle se concentre exclusivement sur la quantification du mouvement de la colonne cervicale, un critère de substitution qui ne constitue qu'un seul des nombreux facteurs qui peuvent potentiellement avoir un impact sur le devenir clinique des patients présentant une lésion de la colonne cervicale. Étant donné que le choix d'une technique de prise en charge des voies aériennes pourrait influencer des déterminantes importantes du devenir clinique, telles que la durée de l'hypoxémie et l'instabilité hémodynamique, les études comparant l'effet de différentes techniques sur des critères cliniques tels que le pronostic neurologique seraient plus souhaitables. Toutefois, étant donné la difficulté de réaliser des études rigoureuses d'un point de vue méthodologique s'intéressant à cette question, nous devons compter sur des présentations de cas et des séries de cas, qui elles aussi comportent leurs limites, afin d'évaluer l'impact de la prise en charge des voies aériennes sur le pronostic neurologique de patients atteints d'instabilité de la colonne cervicale.

Malgré le fait que la prise en charge des voies aériennes chez les patients souffrant d'instabilité de la colonne cervicale soit relativement fréquente dans la pratique clinique, le nombre réel de cas dans lesquels il a été allégué qu'elle avait provoqué une détérioration neurologique est restreint; de plus, dans nombre de ces cas, le lien causal entre prise en charge des voies aériennes et lésion neurologique est ténu. ${ }^{30}$ En outre, de nombreuses séries de cas portant sur des nombres appréciables de patients avec une colonne cervicale instable dont les voies aériennes ont été prises en charge - souvent par LD sous anesthésie générale - n'ont rapporté aucune détérioration neurologique après l'intubation. ${ }^{31,32}$ Bien que ces études pourraient souffrir de biais de publication ou manquer de puissance pour déceler les évènements rares, elles indiquent néanmoins, dans leur ensemble, que le risque de provoquer une lésion neurologique secondaire lors de la prise en charge des voies aériennes pourrait être moins important qu'on le présupposait. ${ }^{30}$ Un compte-rendu récent examinant la base de données des demandes de dédommagement closes (Closed Claims) de l'American Society of Anesthesiologists a révélé que la plupart des incidents de lésions de la colonne cervicale liés à l'anesthésie sont survenus non pas chez des patients traumatisés, mais chez des patients sains subissant une chirurgie non urgente et non traumatologique et dont la colonne cervicale semblait stable. ${ }^{33}$

\section{Autres considérations}

Une telle évaluation de la littérature devrait pousser les anesthésiologistes à élargir leur horizon lorsqu'ils doivent prendre soin d'un patient présentant une instabilité potentielle de la colonne cervicale: il est important de minimiser le mouvement de la colonne cervicale, mais il est tout aussi essentiel de protéger rapidement et efficacement les voies aériennes dans bon nombre de situations urgentes. L'hypoxémie et l'hypercarbie provoquées par des voies aériennes non protégées ou des manipulations prolongées des voies aériennes sont particulièrement délétères pour les patients atteints de lésions neurologiques; elles devraient être évitées à tout prix.

Le choix de la technique de prise en charge des voies aériennes

Chaque dispositif de prise en charge des voies aériennes comporte ses propres avantages et inconvénients, et le 
choix le plus adapté dépendra souvent de l'expérience du praticien avec une technique en particulier et de la situation clinique spécifique. Par exemple, le bronchoscope à fibre optique procure une grande stabilité de la colonne cervicale si ce dispositif est entre des mains compétentes chez un patient coopératif et bien préparé. En revanche, cette modalité est souvent mal adaptée aux situations rencontrées en traumatologie: en effet, ces patients sont fréquemment peu coopératifs, ont du sang et des sécrétions dans leurs voies aériennes, ce qui rend la préparation et la visualisation des voies aériennes difficiles, et ils requièrent souvent une prise en charge immédiate des voies aériennes. D'autre part, la LD est associée à un peu plus de mouvement de la colonne cervicale et pourrait être plus difficile à réaliser avec une immobilisation de la colonne cervicale; néanmoins, cette technique est plus rapide et plus pratique, les sécrétions et le sang présents dans les voies aériennes ayant moins d'impact sur sa réalisation. Enfin, la vidéolaryngoscopie offre une meilleure visualisation glottique que la $\mathrm{LD}$ en présence de SMEL ${ }^{27}$ mais prend en général plus de temps à réaliser. ${ }^{25}$

\section{Résumé et conclusions}

La prise en charge optimale des voies aériennes lorsqu'il y a instabilité potentielle de la colonne cervicale nécessite une connaissance de l'anatomie de base de la colonne cervicale ainsi qu'une compréhension des modalités d'évaluation de la stabilité, d'immobilisation de la colonne cervicale, et de sélection d'une technique de prise en charge des voies aériennes adaptée. En termes d'évaluation clinique et d'imagerie, des recommandations solides qui s'appuient sur des directives fondées sur des données probantes peuvent être émises:

1. l'anamnèse et l'examen physique sont suffisants pour confirmer la stabilité de la colonne cervicale chez les patients à faible risque ayant subi un traumatisme contondant et répondant aux critères NEXUS ou CCR; et

2. il faut impérativement réaliser un tomodensitogramme en tranches minces de la colonne entre l'occiput et T1 chez tous les autres patients dont le risque est plus élevé.

Quant à l'immobilisation, les recommandations concordent; en revanche, elles s'appuient sur peu de données probantes et les techniques recommandées comportent toutes des inconvénients:

1. un collet cervical rigide, des sacs de sable, du ruban adhésif et une planche dorsale, ou une variante de ces éléments, devraient être utilisés pour immobiliser la colonne cervicale des patients traumatisés, et il faut s'efforcer de sécuriser rapidement la colonne cervicale afin d'éviter les complications liées à une immobilisation prolongée; et

2. parce que la technique d'immobilisation habituelle entrave considérablement la prise en charge des voies aériennes, la partie antérieure du collet rigide devrait être retirée et une SMEL réalisée lors de la prise en charge des voies aériennes, en gardant à l'esprit que la LD sera probablement plus difficile à réaliser dans un tel contexte.

Concernant le choix d'une technique de prise en charge des voies aériennes, il n'existe aucune directive. Les techniques actuellement utilisées se fondent sur des présentations et des séries de cas, et elles semblent être plus sécuritaires qu'on ne le pensait. Bien que la minimisation du mouvement de la colonne cervicale demeure un objectif important, d'autres objectifs apparaissent dans des contextes cliniques spécifiques, comme par exemple la protection rapide et efficace des voies aériennes afin de prévenir l'hypoxie et l'hypercarbie; ces objectifs ne doivent pas être négligés. Différentes techniques offrent différents avantages et comportent différentes limites; par conséquent, leur choix devrait se fonder sur la situation clinique spécifique et sur l'expérience du praticien.

\section{Cas clinique}

Un homme de 25 ans est amené à l'urgence après que sa voiture eut heurté un gros arbre lors de son retour à la fin d'une soirée avec des amis. À son arrivée, il est orienté, nie toute douleur au cou, mais se plaint de sensibilité prononcée au niveau de l'abdomen. Il devient de plus en plus confus et agité et sa tension artérielle commence à chuter malgré une réanimation liquidienne vigoureuse. Il est de corpulence musculaire, mesure $1,85 \mathrm{~m}$ et pèse 100 $\mathrm{kg}$. Son pouls est de $123 \mathrm{~min}^{-1}$, sa tension artérielle de 93/ $51 \mathrm{mmHg}$, et sa saturation d'oxygène $\left(\mathrm{SpO}_{2}\right)$ est à $97 \%$ avec $100 \%$ d' $\mathrm{O}_{2}$ administré par masque. L'ouverture de la bouche est difficile à évaluer étant donné que le patient est devenu non coopératif; il semble qu'il y ait du sang dans les voies aériennes, la distance thyromentale est normale, le cou est court et fort. L'entrée d'air est égale des deux côtés. Une échographie selon le Focused Assessment with Sonography in Trauma (FAST) confirme la présence de liquide dans l'abdomen.

\section{Directives pour compléter le module de développement professionnel continu (DPC)}

1. Lisez cet article et les références en gras.

2. Allez à: https://www.cpass2.umontreal.ca/selfassessment program/ et sélectionnez le module actuel (La prise en 
charge des voies aériennes chez le patient présentant une instabilité potentielle de la colonne cervicale).

3. Répondez aux questions à choix de réponses concernant le cas clinique.

4. Une fois que vous avez saisi toutes vos réponses, vous aurez accès aux explications d'experts pour tous les choix possibles.

5. Les participants peuvent réclamer un maximum de quatre heures de DPC pour un total de 12 crédits sous la Section 3 du programme de DPC du Collège royal des médecins et chirurgiens du Canada.

Funding None.

Competing interests None declared.

\section{References}

1. Johnson RM, Wolf JW. Stability. In: Society TCSR, editor. The Cervical Spine. Philadelphia: JB Lipppincott; 1983. p. 35-53.

2. Joff $M H$, White AA, Panjabi MM. Clinically relevant kinematics of the cervical spine. In: Cervical Spine Research Society, editor. The Cervical Spine. 2nd ed. Philadelphia: JB Lippincott; 1989. p. 57-69.

3. Reid DC, Henderson R, Saboe L, Miller JD. Etiology and clinical course of missed spine fractures. J Trauma 1987; 27: 980-6.

4. Como JJ, Diaz JJ, Dunham CM, et al. Practice management guidelines for identification of cervical spine injuries following trauma: update from the eastern association for the surgery of trauma practice management guidelines committee. J Trauma 2009; 67: 651-9.

5. Hoffman JR, Mower WR, Wolfson AB, Todd KH, Zucker MI. Validity of a set of clinical criteria to rule out injury to the cervical spine in patients with blunt trauma. National Emergency X-Radiography Utilization Study Group. N Engl J Med 2000; 343: 94-9.

6. Stiell IG, Wells GA, Vandemheen KL, et al. The Canadian $\mathrm{C}$-spine rule for radiography in alert and stable trauma patients. JAMA 2001; 286: 1841-8.

7. Stiell IG, Clement CM, McKnight RD, et al. The Canadian $\mathrm{C}$-spine rule versus the NEXUS low-risk criteria in patients with trauma. N Engl J Med 2003; 349: 2510-8.

8. Duane TM, Dechert T, Wolfe LG, Aboutanos MB, Malhotra AK, Ivatury $R R$. Clinical examination and its reliability in identifying cervical spine fractures. J Trauma 2007; 62: 1405-8. discussion 1408-10.

9. Daffner RH, Hackney DB. ACR appropriateness criteria on suspected spine trauma. J Am Coll Radiol 2007; 4: 762-75.

10. Anonymous. Radiographic assessment of the cervical spine in symptomatic trauma patients. Neurosurgery 2002; 50(3 Suppl): S36-43.

11. Podolsky S, Baraff LJ, Simon RR, Hoffman JR, Larmon B, Ablon $W$. Efficacy of cervical spine immobilization methods. J Trauma 1983; 23: 461-5.

12. American College of Surgeons Committee on Trauma. Advanced Trauma Life Support for Doctors. ATLS Student Course Manual, 7th ed. 2004. Available from URL: https://web4.facs.org/ ebusiness/ProductCatalog/ProductCategory.aspx?id=26 (accessed September 2011).
13. Anonymous. Cervical spine immobilization before admission to the hospital. Neurosurgery 2002; 50(3 Suppl): S7-17.

14. Kwan I, Bunn F, Roberts I. Spinal immobilisation for trauma patients. Cochrane Database Syst Rev 2001; (2): CD002803.

15. Hunt $K$, Hallworth $S$, Smith $M$. The effects of rigid collar placement on intracranial and cerebral perfusion pressures. Anaesthesia 2001; 56: 511-3.

16. Goutcher CM, Lochhead V. Reduction in mouth opening with semi-rigid cervical collars. Br J Anaesth 2005; 95: 344-8.

17. Manoach $S$, Paladino L. Manual in-line stabilization for acute airway management of suspected cervical spine injury: historical review and current questions. Ann Emerg Med 2007; 50: 236-45.

18. Nolan JP, Wilson ME. Orotracheal intubation in patients with potential cervical spine injuries. An indication for the gum elastic bougie. Anaesthesia 1993; 48: 630-3.

19. Thiboutot F, Nicole PC, Trepanier CA, Turgeon AF, Lessard MR. Effect of manual in-line stabilization of the cervical spine in adults on the rate of difficult orotracheal intubation by direct laryngoscopy: a randomized controlled trial. Can J Anesth 2009; 56: 412-8.

20. Heath KJ. The effect on laryngoscopy of different cervical spine immobilisation techniques. Anaesthesia 1994; 49: 843-5.

21. Crosby ET. Airway management in adults after cervical spine trauma. Anesthesiology 2006; 104: 1293-318.

22. Sawin PD, Todd MM, Traynelis VC, et al. Cervical spine motion with direct laryngoscopy and orotracheal intubation. An in vivo cinefluoroscopic study of subjects without cervical abnormality. Anesthesiology 1996; 85: 26-36.

23. Hauswald M, Sklar DP, Tandberg D, Garcia JF. Cervical spine movement during airway management: cinefluoroscopic appraisal in human cadavers. Am J Emerg Med 1991; 9: 535-8.

24. Brimacombe J, Keller C, Kunzel KH, Gaber O, Boehler M, Puhringer $F$. Cervical spine motion during airway management: a cinefluoroscopic study of the posteriorly destabilized third cervical vertebrae in human cadavers. Anesth Analg 2000; 91: 1274-8.

25. Turkstra TP, Craen RA, Pelz DM, Gelb AW. Cervical spine motion: a fluoroscopic comparison during intubation with lighted stylet, GlideScope, and Macintosh laryngoscope. Anesth Analg 2005; 101: 910-5.

26. Helliwell V, Gabbott DA. The effect of single-handed cricoid pressure on cervical spine movement after applying manual inline stabilisation - a cadaver study. Resuscitation 2001; 49: 53-7.

27. Robitaille A, Williams SR, Tremblay $M H$, Guilbert $F$, Theriault $M$, Drolet $P$. Cervical spine motion during tracheal intubation with manual in-line stabilization: direct laryngoscopy versus GlideScope videolaryngoscopy. Anesth Analg 2008; 106: 935-41.

28. Houde BJ, Williams SR, Cadrin-Chenevert A, Guilbert F, Drolet $P$. A comparison of cervical spine motion during orotracheal intubation with the trachlight(r) or the flexible fiberoptic bronchoscope. Anesth Analg 2009; 108: 1638-43.

29. Panjabi MM, Thibodeau LL, Crisco JJ 3rd, White AA 3rd. What constitutes spinal instability? Clin Neurosurg 1988; 34: 313-39.

30. McLeod AD, Calder I. Spinal cord injury and direct laryngoscopy - the legend lives on. Br J Anaesth 2000; 84: 705-9.

31. Suderman VS, Crosby ET, Lui A. Elective oral tracheal intubation in cervical spine-injured adults. Can J Anaesth 1991; 38: 785-9.

32. Shatney CH, Brunner RD, Nguyen $T Q$. The safety of orotracheal intubation in patients with unstable cervical spine fracture or high spinal cord injury. Am J Surg 1995; 170: 676-9. discussion 679-80.

33. Hindman BJ, Palecek JP, Posner KL, et al. Cervical spinal cord, root, and bony spine injuries: a closed claims analysis. Anesthesiology 2011; 114: 782-95. 